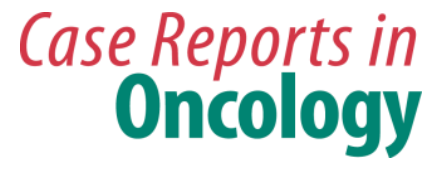

Case Rep Oncol 2016;9:781-785

DOI: 10.1159/000452791

Publisnea onune:TNovember 18, 2016

This article is licensed under the Creative Commons Attribution-NonCommercial 4.0 International License (CC BY-NC) (http://www.karger.com/Services/OpenAccessLicense) Usage and distribution for commercial purposes requires written permission.

\title{
Urgent Coronary Artery Bypass Surgery in a Patient with Postinfarction Angina and Active Myelomonocytic Leukaemia
}

\author{
Samuel Anthony Galea Joseph Galea \\ Department of Cardiothoracic Surgery, Mater Dei Hospital, Msida, Malta
}

\section{Keywords}

Chronic myelomonocytic leukaemia · Cardiac surgery · Cardiopulmonary bypass .

Inflammatory response $\cdot$ Myelomonocytic leukaemoid reaction

\begin{abstract}
Chronic myelomonocytic leukaemia (CMML) is a myelodysplastic/myeloproliferative neoplasm affecting the production and differentiation of the monocyte cell lineage. Cardiac surgery in the context of CMML poses challenges that are not routinely encountered. This is the first reported case in the literature of a patient with active CMML undergoing urgent onpump coronary artery bypass grafting. A 68-year-old Caucasian man with a history of hypertension, hyperlipidaemia, hypothyroidism, and hypercholesterolaemia, who had been diagnosed by the haematologists with CMML a few months earlier but had remained untreated, underwent urgent surgical coronary revascularisation because of postinfarction angina following a non-ST elevation myocardial infarction associated with troponin I rise. The patient had fulminant postoperative myelomonocytic leukaemoid reaction, with a clinical picture of severe systemic inflammatory response syndrome and multiple organ dysfunction syndrome. This led to extensive vasodilation and heart failure that resulted in the death of the patient.
\end{abstract}




\section{Case Reports in Oncology}

Galea and Galea: Urgent Coronary Artery Bypass Surgery in a Patient with Postinfarction Angina and Active Myelomonocytic Leukaemia

Various authors have suggested different techniques and treatment options, each attempting to mitigate the effect of the postoperative inflammatory response. However, this is a highrisk endeavour with a myriad of inflammatory signals mobilised into action because of the surgical insult. Off-pump surgery or preoperative pharmacological attenuation of CMML activity might have dampened this response and resulted in a positive outcome for the patient.

(C) 2016 The Author(s)

Published by S. Karger AG, Basel

\section{Introduction}

Chronic myelomonocytic leukaemia (CMML) is a myelodysplastic/myeloproliferative neoplasm affecting the production and differentiation of the monocyte cell lineage. A complete blood count would demonstrate a persistent monocytosis of $>1,000 / \mathrm{mm}^{3}$ in the peripheral blood and $<20 \%$ of blasts in peripheral blood and bone marrow. Other features of this disease may also affect other cell lineages producing dysplastic neutrophils, often accompanied by anaemia and/or thrombocytopenia. Cytogenetic studies may reveal the absence of the $t(9 ; 22)$ chromosome and rearrangement of PDGFR- $\alpha$ and $-\beta$ gene, especially if eosinophilia is present [1].

The current mortality risk calculators used for cardiac surgery do not account for haematological malignancy. Several studies have concluded that patients with haematological malignancy carry an increased risk of complications [2-4]. Data available so far are based on case reports, as there are an insufficient number of cases to build a concrete meta-analysis of the subject. Different authors report various problems that these patients are at risk of; however, bleeding and infections are by far the commonest. Only 1 other case of a patient with CMML undergoing elective on-pump coronary artery bypass grafting (CABG) has been described in the literature [5]. The following case report exemplifies the difficult nature in the acute postoperative period that these patients face.

\section{Case Presentation}

A 68-year-old Caucasian gentleman was diagnosed with CMML by the haematologists in May 2015, and no treatment was commenced for this condition. On September 10, 2015 he was referred for urgent surgical coronary revascularisation because of postinfarction angina following a non-ST elevation myocardial infarction associated with troponin I rise (peak troponin I $=0.110 \mathrm{ng} / \mathrm{mL}$; normal range 0.006-0.04) 2 days earlier. On angiography the patient had triple-vessel disease with impaired left ventricular ejection fraction (51\%). His Euroscore and logistic Euroscore were 4 and 4.7\%, respectively. The haematologists were consulted and they advised to go ahead with the urgent cardiac surgery, but no treatment for the CMML was advised because the disease was deemed stable.

Percutaneous coronary intervention was not pursued because of unsatisfactory coronary lesion anatomy, and urgent CABG was performed within 7 days of his myocardial infarction utilising a left internal mammary artery graft to the left anterior descending artery and a long saphenous vein graft to the posterior descending artery. Both grafts had good 


\section{Case Reports in Oncology}

Galea and Galea: Urgent Coronary Artery Bypass Surgery in a Patient with Postinfarction Angina and Active Myelomonocytic Leukaemia

flow with good target vessels. Multidose antegrade cold blood cardioplegia was used with an ischaemic and cardiopulmonary bypass (CPB) time of 37 and $102 \mathrm{~min}$, respectively. The patient had a pulmonary artery flotation catheter inserted and cardiac output and systemic vascular resistance monitored. High doses of vasopressor were required to wean the patient off CPB. His blood pressure was low, with a high cardiac output and low systemic resistance. Full reversal of heparin was performed with the administration of protamine. At the time of closure the patient remained hypotensive and tachycardic, requiring high vasopressor support, and was transferred to the cardiac intensive care unit. Immediately postoperatively thromboelastography revealed hyperfibrinolysis, and a blood fibrinogen assay showed $0.62 \mathrm{~g} / \mathrm{L}$ (normal range 1.56-4.00), thus fibrinogen was given. D-dimer was 1,922 $\mu \mathrm{g} / \mathrm{L}$ (normal range $0-500$ ), showing evidence of disseminated intravascular coagulation. The patient remained hypotensive and the loss of blood did not explain the degree of hypotension comprehensively. Initially there were no ischaemic changes on ECG and a bedside echocardiogram showed moderately impaired left ventricular function. His blood tests $1 \mathrm{~h}$ postoperatively showed exaggerated leukocytosis of $136 \times 10^{9} / \mathrm{L}$ (Table 1). These changes indicated that the patient had developed an acute leukaemoid reaction with massive vascular dilation. Despite a high amount of vasopressors (noradrenaline at $0.35 \mu \mathrm{g} / \mathrm{kg} / \mathrm{min}$ ), prolonged hypotension led to ischaemic changes on ECG and echocardiography. Ventricular fibrillation ensued and despite prolonged attempts at resuscitation, the patient succumbed.

\section{Discussion}

Contact of blood with non-epithelial surfaces, such as the CPB circuitry, causes an inflammatory process mediated by the release of inflammatory cytokines. These mediators cause vasodilation and non-vascular smooth muscle contraction as well as neutrophil activation and augmentation of fibrinolysis. Complement activation increases capillary permeability, vasodilation, and activation of neutrophils and platelets [6]. In view of the negative effects that proinflammatory mediators have in the context of cardiac surgery, the use of steroids as an anti-inflammatory agent has been suggested [7]; however, the effect of steroids on clinical outcomes remains controversial. Cardiac surgery produces an altered activation of the inflammatory response due to the combination of surgical trauma, CPB, and ischaemiareperfusion injury [5]. Marked amplification of this process can result in systemic inflammatory response syndrome. Some patients with CMML may progress to the acute phase of myeloid leukaemia as a response by the bone marrow to stress. In our patient, it appears that the inflammatory storm generated by cardiac surgery with CPB precipitated a dramatic myelomonocytic leukaemoid reaction, with a clinical picture of systemic inflammatory response syndrome and multiple organ dysfunction syndrome. This led to extensive vasodilation and heart failure that resulted in the death of the patient. This devastating reaction is similar to the one in the only other patient described in the literature who underwent CABG with CMML and who had the same fate [5]. That patient described by Drury et al. was operated electively, had stable angina, and had an undiagnosed CMML with a relatively low preoperative white blood cell count $\left(14.2 \times 10^{9} / \mathrm{L}\right)$. It has been suggested that off-pump CABG elicits an attenuated inflammatory response $[8,9]$. It is also possible that preoperative drug control 


\section{Case Reports in Oncology}

Galea and Galea: Urgent Coronary Artery Bypass Surgery in a Patient with Postinfarction Angina and Active Myelomonocytic Leukaemia

of the activity of the underlying haematological disease might have attenuated the leukaemoid response and resulted in a positive outcome.

\section{Statement of Ethics}

The authors have no ethical conflicts to disclose.

\section{Disclosures Statement}

The authors have no financial or institutional affiliations to disclose.

\section{References}

Zachée P: Atypical myeloproliferative disorders in adults. Transfus Apher Sci 2011;44:211-221. Potapov EV, Zurbrügg HR, Herzke C, Srock S, Riess H, Sodian R, Hübler S, Hetzer R: Impact of cardiac surgery using cardiopulmonary bypass on course of chronic lymphatic leukemia: a case-control study. Ann Thorac Surg 2002;74:384-389.

3 Christiansen S, Schmid C, Löher A, Scheld HH: Impact of malignant hematological disorders on cardiac surgery. Cardiovasc Surg 2000;8:149-152.

4 Bala S, Vaynblat M, Dhadwal A, Cunningham J: Cardiac surgery in patients with hematological malignancies. Chest 2004;126:831S.

5 Drury N, Ali A, Mussa S, Webb S, Rege K, Wallwork J: Acute leukaemoid reaction following cardiac surgery. J Cardiothorac Surg 2007;2:3.

-6 Augoustides JG: The inflammatory response to cardiac surgery with cardiopulmonary bypass: should steroid prophylaxis be routine? J Cardiothorac Vasc Anesth 2012;26:952-958.

7 Murphy G, Whitlock R, Gutsche J, Augoustides JG: Steroids for adult cardiac surgery with cardiopulmonary bypass: update on dose and key randomized trials. J Cardiothorac Vasc Anesth 2013;27:1053-1059.

-8 Shekar PS: Cardiology patient page. On-pump and off-pump coronary artery bypass grafting. Circulation 2006;113:e51-e52.

-9 Ito K, Kawachi H, Nishiyama K, Yaku H, Kitamura N: Off-pump coronary artery bypass grafting in a patient with chronic myelomonocytic leukemia. Jpn Heart J 2003;44:435-439. 


\section{Case Reports in Oncology}

\begin{tabular}{l|l}
\hline DOI: $10.1159 / 000452791$ & (C) 2016 The Author(s). Published by S. Karger AG, Basel
\end{tabular} www.karger.com/cro

Galea and Galea: Urgent Coronary Artery Bypass Surgery in a Patient with Postinfarction Angina and Active Myelomonocytic Leukaemia

Table 1. Table depicting the evolution of the results of full blood count in the preoperative and the immediate postoperative phase

\begin{tabular}{lllll}
\hline Leukocyte indices & $\begin{array}{l}\text { Time of CMML } \\
\text { diagnosis } \\
(5 / 7 / 2015)\end{array}$ & $\begin{array}{l}\text { Day 2, NSTEMI } \\
\text { admission } \\
(9 / 10 / 2015)\end{array}$ & $\begin{array}{l}\text { 1 day before } \\
\text { CABG } \\
(9 / 16 / 2015)\end{array}$ & $\begin{array}{l}\text { 1 h after surgery } \\
\text { admission to ICU } \\
(9 / 16 / 2015)\end{array}$ \\
\hline White blood cell count & $52.3 \times 10^{9} / \mathrm{L}$ & $87.19 \times 10^{9} / \mathrm{L}$ & $81.78 \times 10^{9} / \mathrm{L}$ & $135.98 \times 10^{9} / \mathrm{L}$ \\
Neutrophils & $44.7 \times 10^{9} / \mathrm{L}$ & $73.87 \times 10^{9} / \mathrm{L}$ & $69.14 \times 10^{9} / \mathrm{L}$ & $96.73 \times 10^{9} / \mathrm{L}$ \\
Immature granulocytes & $1.62 \times 10^{9} / \mathrm{L}$ & $5.36 \times 10^{9} / \mathrm{L}$ & $5.53 \times 10^{9} / \mathrm{L}$ & $24.98 \times 10^{9} / \mathrm{L}$ \\
Lymphocytes & $4.35 \times 10^{9} / \mathrm{L}$ & $4.60 \times 10^{9} / \mathrm{L}$ & $4.40 \times 10^{9} / \mathrm{L}$ & $10.43 \times 10^{9} / \mathrm{L}$ \\
Monocytes & $1.61 \times 10^{9} / \mathrm{L}$ & $2.31 \times 10^{9} / \mathrm{L}$ & $1.93 \times 10^{9} / \mathrm{L}$ & $3.16 \times 10^{9} / \mathrm{L}$ \\
Eosinophils & $0.06 \times 10^{9} / \mathrm{L}$ & $0.43 \times 10^{9} / \mathrm{L}$ & $0.43 \times 10^{9} / \mathrm{L}$ & $0.36 \times 10^{9} / \mathrm{L}$ \\
Basophils & $0.19 \times 10^{9} / \mathrm{L}$ & $0.33 \times 10^{9} / \mathrm{L}$ & $0.35 \times 10^{9} / \mathrm{L}$ & $0.32 \times 10^{9} / \mathrm{L}$ \\
\hline
\end{tabular}

CABG, coronary artery bypass grafting; CMML, chronic myelomonocytic leukaemia; ICU, intensive care unit; NSTEMI, non-ST elevation myocardial infarction. 